\title{
First Version
}

\section{Kinetics of Oxychlorination of Chromite : Part I. Effect of Temperature}

\author{
N. KANARI, I. GABALLAH and E. ALLAIN* \\ Mineral Processing and Environmental Engineering team, \\ LEM $^{\mathrm{a}}, \mathrm{CNRS}^{\mathrm{b}} \mathrm{UMR}^{7569}, \mathrm{ENSG}^{\mathrm{c}}, \mathrm{INPL}^{\mathrm{d}}$, BP 40, 54501 Vandœuvre, France \\ * University of Missouri-Rolla, School of Mines and Metallurgy, Center for Pyrometallurgy \\ 210 Fulton Hall, 65401 Rolla, MO, USA
}

Nonisothermal TG analysis was used to evaluate the reactivity of a chromite mineral $\left[\left(\mathrm{Fe}^{2+}, \mathrm{Mg}\right)\left(\mathrm{Cr}, \mathrm{Al}, \mathrm{Fe}^{3+}\right)_{2} \mathrm{O}_{4}\right]$ towards $\mathrm{Cl}_{2}+\mathrm{CO}, \mathrm{Cl}_{2}+\mathrm{N}_{2}$ and $\mathrm{Cl}_{2}+\mathrm{O}_{2}$ gaseous mixtures up to 1000 ${ }^{\circ} \mathrm{C}$. Full chlorination and volatilization of reaction products were achieved at about $975{ }^{\circ} \mathrm{C}$ using $\mathrm{Cl}_{2}+\mathrm{CO}$, while only about 40 pct of the sample have reacted at $1000{ }^{\circ} \mathrm{C}$ using $\mathrm{Cl}_{2}+\mathrm{N}_{2}$ and $\mathrm{Cl}_{2}+\mathrm{O}_{2}$.

The effect of the temperature on the oxychlorination with $\mathrm{Cl}_{2}+\mathrm{O}_{2}$ of the chromite mineral was studied between $600{ }^{\circ} \mathrm{C}$ and $1050{ }^{\circ} \mathrm{C}$ using isothermal TG measurements. The results show that the oxychlorination of chromite occurs in two stages. The initial stage of the oxychlorination was characterized by the average values of apparent activation energy of about 151 and $57 \mathrm{~kJ} / \mathrm{mol}$ for the temperatures lower and higher than $825^{\circ} \mathrm{C}$, respectively. While a value of about of $262 \mathrm{~kJ} / \mathrm{mol}$ was found for the second stage of the oxychlorination process between $925^{\circ} \mathrm{C}$ and $1050{ }^{\circ} \mathrm{C}$. The effects of temperature on the oxychlorination of the simple chromite constituents $\left(\mathrm{Cr}_{2} \mathrm{O}_{3}, \mathrm{Fe}_{2} \mathrm{O}_{3}\right.$ and $\mathrm{MgO}$ ) were also given.

\footnotetext{
a. Laboratoire Environnement et Minéralurgie, rue du Doyen M. Roubault, BP 40, 54501 Vandœuvre Cedex, France.

b. Centre National de la Recherche Scientifique, 3 rue Michel-Ange, 75794 Paris Cedex, France.

c. École Nationale Supérieure de Géologie, rue du Doyen M. Roubault, BP 40, 54501 Vandœuvre Cedex, France.

d. Institut National Polytechnique de Lorraine, 2 rue de la Forêt de Haye, 54501 Vandœuvre Cedex, France.
} 


\section{INTRODUCTION}

Chlorination is an important step for the recovery of several metals such as $\mathrm{Ti}, \mathrm{Zr}, \mathrm{Hf}, \mathrm{Nb}$, Ta, rare-earth elements, etc. from their bearing materials. An overview concerning the applications and potential uses of chlorination methods in metallurgy of these metals was detailed by Korshunov[1]. The author described the theoretical aspects of the chlorination, methods and apparatus used as well as the industrial application of the chlorine technology. As the majority of the above-mentioned elements occurred as oxides in earth crust, a reducing agent $(\mathrm{C}, \mathrm{CO})$ was added in the chlorination process to increase its efficiency.

However, the chlorination in the presence of oxygen (oxychlorination) was sometimes used to separate selectively a group of elements from the others. This is supported by the fact that the presence of the oxygen in the system could lead to different thermodynamic feasibility of the specific oxychlorination reactions. Recently, Gaballah and Djona ${ }^{[2]}$ proposed the chlorination with $\mathrm{Cl}_{2}$ +air of the spent hydrorefining catalysts in order to recover selectively $\mathrm{Co}, \mathrm{Ni}$, Mo, and $\mathrm{V}$ chlorinated compounds and to prevent the chlorination of the catalyst support $\left(\mathrm{Al}_{2} \mathrm{O}_{3}\right)$. In previous investigations [3-6], we used the oxychlorination for the upgrading of the chromite concentrates as well as for the partial recovery of chromium as chromium oxychloride $\left(\mathrm{CrO}_{2} \mathrm{Cl}_{2}\right)$ almost pure.

This paper is devoted to the study of the effect of temperature on the oxychlorination of the chromite mineral in the absence of the mass transfer phenomenon. To our knowledge, no studies concerning the oxychlorination of chromite are reported in the literature.

\section{MATERIALS AND EXPERIMENTAL PROCEDURE}

The sample used in this study is a chromite mineral obtained from its concentrate described in details previously[7]. Microprobe analyses revealed the following weight composition of this chromite mineral, considered as simple oxides : 59.4 pct $\mathrm{Cr}_{2} \mathrm{O}_{3}, 13.9$ pct $\mathrm{FeO}, 14.2$ pct $\mathrm{MgO}, 9.5$ pct $\mathrm{Al}_{2} \mathrm{O}_{3}$, and 0.1 pct $\mathrm{SiO}_{2}$. The first four oxides are included in the chromite structure belonging to spinel one. Based on the microprobe data, the general formula of chromite sample could be given as : $\left(\mathrm{Fe}^{2+}{ }_{0.30}, \mathrm{Mg}_{0.70}\right)\left(\mathrm{Cr}_{1.56}, \mathrm{Al}_{0.37}, \mathrm{Fe}^{3+}{ }_{0.07}\right) \mathrm{O}_{4}$. On the other hand, this solid could be represented as the simple spinels of weight composition : 30.9 pct $\mathrm{FeCr}_{2} \mathrm{O}_{4}, 51.0$ pct $\mathrm{MgCr}_{2} \mathrm{O}_{4}, 13.7$ pct $\mathrm{MgAl}_{2} \mathrm{O}_{4}$ and 4.4 pct $\mathrm{Fe}_{3} \mathrm{O}_{4}$.

The thermogravimetric 'TG' chlorination tests were realized with $40 \mathrm{mg}$ of the sample, using the experimental setup described earlier[7]. Some oxychlorination tests, using several grams of sample, were carried out in a horizontal experimental setup described also in Reference [7]. 


\section{RESULTS AND DISCUSSION}

\section{A. Nonisothermal TGA Treatment in Various Chlorinating Atmospheres}

This study was started by nonisothermal TGA treatment of the chromite mineral in $\mathrm{Cl}_{2}+\mathrm{CO}\left(\mathrm{Cl}_{2} / \mathrm{CO}=1\right), \mathrm{Cl}_{2}+\mathrm{N}_{2}\left(\mathrm{Cl}_{2} / \mathrm{N}_{2}=1\right)$, and $\mathrm{Cl}_{2}+\mathrm{O}_{2}\left(\mathrm{Cl}_{2} / \mathrm{O}_{2}=4\right)$ gaseous mixtures in order to evaluate its reactivity towards these chlorinating gaseous mixtures between $25^{\circ} \mathrm{C}$ and $1000{ }^{\circ} \mathrm{C}$. The heating rate of the sample was about $7^{\circ} \mathrm{C} / \mathrm{min}$. Figure 1 (a) shows the evolution of the percent weight loss (PWL) of chromite sample as a function of temperature for the chosen gaseous mixtures and for the temperature higher than $400{ }^{\circ} \mathrm{C}$. Almost sample was reacted with $\mathrm{Cl}_{2}+\mathrm{CO}$ at temperatures approaching $975{ }^{\circ} \mathrm{C}$ while about 40 pct of the sample were chlorinated in $\mathrm{Cl}_{2}+\mathrm{N}_{2}$ and/or $\mathrm{Cl}_{2}+\mathrm{O}_{2}$ gas mixtures up to $1000{ }^{\circ} \mathrm{C}$ indicating a relatively low reactivity of chromite towards these chlorinating gaseous mixtures.

The derivative of weight loss versus temperature is reported in Figure 1 (b). Two maximums of reaction rate at about $655^{\circ} \mathrm{C}$ and $890{ }^{\circ} \mathrm{C}$ are observed during the carbochlorination of the sample. The chlorination and the oxychlorination of chromite sample proceed with the maximal reaction rates at about $725{ }^{\circ} \mathrm{C}$ and $775{ }^{\circ} \mathrm{C}$, respectively. Beyond these temperatures, the reaction rate decreases strongly with the increase of the temperature. The examination of Figures 1 (a) and (b) revealed that, at least, two different constituents of chromite possess different reactivities towards the three chlorinating gas mixtures. As the first approximation, it seems that $\mathrm{Fe}_{3} \mathrm{O}_{4}$ and $\mathrm{FeCr}_{2} \mathrm{O}_{4}$ (iron chromite) were the first to be reacted with reactive gases. The weight loss calculated for the chlorination of these compounds (refer to $\mathrm{L}_{1} \mathrm{Ch}$ in Figure 1 a) agrees with those obtained at about $900{ }^{\circ} \mathrm{C}$ during the chlorination using $\mathrm{Cl}_{2}+\mathrm{N}_{2}$ and $\mathrm{Cl}_{2}+\mathrm{O}_{2}$ gas mixture. $\mathrm{MgCr}_{2} \mathrm{O}_{4}$ (magnesium chromite) and $\mathrm{MgAl}_{2} \mathrm{O}_{4}$ appear to be more stable in chlorine in the absence of a reducing atmosphere. This is in good agreement with the thermodynamical predictions ${ }^{[4]}$. In the case of the carbochlorination, $\mathrm{CrCl}_{3}, \mathrm{FeCl}_{2 / 3}, \mathrm{MgCl}_{2}, \mathrm{AlCl}_{3}$ are the most probable chlorides of the chromite reactions with $\mathrm{Cl}_{2}+\mathrm{CO}$. Details concerning the kinetics aspects of the chromite carbochlorination are given in a previous article[7].

The main products of the chromite oxychlorination are expected to be $\mathrm{CrO}_{2} \mathrm{Cl}_{2}, \mathrm{FeCl}_{3}$, and $\mathrm{MgCl}_{2}$. The evolution of the vapor pressure of chlorides as a function of the temperature is given in Figure $2^{[8,9]}$. Concerning the oxychlorination, this figure suggests that the chromium oxychloride was volatile at low temperatures and ferric chloride possesses a vapor pressure of about one atmosphere at temperatures approaching $300{ }^{\circ} \mathrm{C}$. On the other hand, using a $\mathrm{Cl}_{2}+\mathrm{O}_{2}$ with a $\mathrm{Cl}_{2} / \mathrm{O}_{2}$ molar ratio equal to 4 led to a volatilization rate of $\mathrm{MgCl}_{2}$ higher than that magnesium chloride formation[10]. Thus, the rate of the chlorides' volatilization will be higher than that of their formation during the oxychlorination of chromite and consequently the measured weight loss is directly related to the oxychlorination rate of the sample. 


\section{B. Isothermal TGA Treatment in $\mathrm{Cl}_{2}+\mathrm{O}_{2}$}

1. Oxychlorination of chromite at $1050{ }^{\circ} \mathrm{C}$

In attempt to obtain more information about the behavior of chromite oxychlorination, the isothermal treatment with $\mathrm{Cl}_{2}+\mathrm{O}_{2}$ gas mixture of a chromite ground sample and a sample of particle size of $125-180 \mu \mathrm{m}$ was conducted at $1050{ }^{\circ} \mathrm{C}$. The evolution of the sample PWL versus time is traced in Figure 3. The time scale is graduated in minutes up to 30 minutes and the rest of chlorination time is given in hours. About 35 pct of sample are chlorinated and volatilized for a reaction time less than 15 minutes. Then, the reaction rate falls sharply and about 12 hours are required to reach 88 PWL whereas the weight loss is stabilized. In both cases, the reaction rate is slightly affected by the particles' size.

The oxychlorination residues corresponding to the extent of reaction ' $\mathrm{X}$ ' (ratio of weight of the reacted fraction to initial weight) equal to $0.40,0.60,0.80$ and 0.88 (points $\mathrm{a}, \mathrm{b}, \mathrm{c}$ and $\mathrm{d}$ in Figure 3) were analyzed by scanning electron microscopy (SEM) and x-ray diffraction (XRD). The SEM spectrums of these residues, as well as that of the raw sample, are grouped in the Figure 4. The residue of point 'a' $(\mathrm{X}=0.40)$ is free of iron but the full elimination of iron oxides can not justify a reaction extent of 0.40 as the iron oxides' content of the chromite is about 14 pct. Only the chlorination of both $\mathrm{FeCr}_{2} \mathrm{O}_{4}$ and $\mathrm{Fe}_{3} \mathrm{O}_{4}$ is in good agreement with an extent of reaction of 0.40 (refer to $\mathrm{L}_{1} \mathrm{Ch}$ in Figure 3). The SEM spectrums of points 'b' and 'c' show the decrease of $\mathrm{Cr}$ peak intensity and the increase of $\mathrm{Mg}$ and $\mathrm{Al}$ ones. Finally, the SEM spectrum of points 'd' is essentially composed of aluminum and magnesium without chromium. The evolution of elemental composition of residues from ' $b$ ' to ' $d$ ' indicates that $\mathrm{MgCr}_{2} \mathrm{O}_{4}$ could be chlorinated leaving the $\mathrm{MgAl}_{2} \mathrm{O}_{4}$ which is less reactive that others compounds of chromite towards $\mathrm{Cl}_{2}+\mathrm{O}_{2}$ gas mixture. The percent weight loss calculated (refer to $\mathrm{L}_{2} \mathrm{Ch}$ in Figure 3) for the chlorination of $\left(\mathrm{FeCr}_{2} \mathrm{O}_{4}+\mathrm{Fe}_{3} \mathrm{O}_{4}+\mathrm{MgCr}_{2} \mathrm{O}_{4}\right)$ were in fair agreement with the observations of Figures 3 and 4 . It is important to note that the chlorine is not detected in the chlorination residues. This confirmed the hypothesis that the reaction rate of chromite with $\mathrm{Cl}_{2}+\mathrm{O}_{2}$ was lower than that of the volatilization one of the generated products.

XRD diagrams of the residues corresponding to points 'a' to ' $d$ ' were almost similar. This is probably due to the fact that spinels $\left(\mathrm{FeCr}_{2} \mathrm{O}_{4}, \mathrm{Fe}_{3} \mathrm{O}_{4}, \mathrm{MgCr}_{2} \mathrm{O}_{4}, \mathrm{MgAl}_{2} \mathrm{O}_{4}\right)$ have the same crystalline structure and lattice parameters making difficult to distinguish them by XRD. Moreover, the removal simultaneous of the divalent $\left(\mathrm{Fe}^{2+}, \mathrm{Mg}\right)$ and trivalent $\left(\mathrm{Fe}^{3+}, \mathrm{Cr}\right)$ elements at same time from the chromite structure could compensate the ionic's radii effects on the lattice parameters. 


\section{Effect of gas flow rate}

The effect of the gas flow rate on the reaction rate was assessed to determine the conditions under which the external mass phenomena could be minimized. A series of experiments was performed at $1000{ }^{\circ} \mathrm{C}$ using the $\mathrm{Cl}_{2}+\mathrm{O}_{2}$ gas mixtures with a $\mathrm{Cl}_{2} / \mathrm{O}_{2}$ molar ratio constant and equal to 4 , while the total gas flow rate was varied from 15 to $75 \mathrm{~L} / \mathrm{h}$. Figure 5 (a) traces the evolution of the PWL as a function of the temperature. A dramatically decrease of the reactivity of sample after about 35 pct of weight loss was observed and it is almost not affected by the gas flow rate. Therefore, the evolution of reaction rate as a function of the gas flow rate was determined for the reaction extents $0.10 \leq X \leq 0.25$ and $0.40 \leq X \leq 0.50$ and it is shown in Figure 5 (b). It may be considered that the gas flow rate has almost not effect on the reaction rate for a gas velocity $\left(\mathrm{V}_{\mathrm{g}}\right)$ higher than $40 \mathrm{~cm} / \mathrm{min}$. Therefore, a chlorinating gas mixture with a $\mathrm{V}_{\mathrm{g}} \approx 49.6 \mathrm{~cm} / \mathrm{min}$ was used for the determination of the temperature effect on the chromite oxychlorination.

\section{Isothermal oxychlorination of chromite at different temperatures}

A series of TGA experiments was carried out in the temperature range from $600{ }^{\circ} \mathrm{C}$ to $1050{ }^{\circ} \mathrm{C}$. As the reaction rate was low for $\mathrm{X}>0.35$, the experiments carried out up to $900{ }^{\circ} \mathrm{C}$ are stooped when a reaction extent of 0.35 is approached. Figures 6 (a) and (b) trace the evolution of the PWL of the chromite sample versus time for several of isotherms performed for the reaction extents up to 0.30 . It is clear from these figures that the time required to reach a given reaction extent decreases with the rise of the treatment temperature. The data of the isothermal oxychlorination of the chromite at temperatures higher than $900{ }^{\circ} \mathrm{C}$ and for reaction extents up to 0.80 are displayed in Figure 7 (d). As it shown, each curve undergoes a change in the slope at about $\mathrm{X}=0.35$ to indicate a sharp fall in the reaction rate. For instance, the reaction rate at $950{ }^{\circ} \mathrm{C}$ is drooped over 130 times.

The temperature dependency of the reaction rate was determined according to Arrhenius diagram. It was interesting to follow the evolution of apparent activation energy $\left(\mathrm{E}_{\mathrm{a}}\right)$ as a function of reaction extent. The variation of $E_{a}$ values with the reaction progress is shown in Figure 7 between $925{ }^{\circ} \mathrm{C}$ and $1050{ }^{\circ} \mathrm{C}$. The value of $\mathrm{E}_{\mathrm{a}}$ at the begging of the reaction is about $80 \mathrm{~kJ} / \mathrm{mol}$ and decreases slightly with the progress of the reaction up to $X \leq 0.25$. An important increase of $E_{a}$ is observed for $X>0.35$ and the average value of activation energy is about $265 \mathrm{~kJ} / \mathrm{mol}$ for $0.40<X$ $<0.70$. It should be pointed out that the sudden change of activation energy coincides roughly with the chlorination of iron chromite $: \mathrm{FeCr}_{2} \mathrm{O}_{4}$ (refer to $\mathrm{L}_{1} \mathrm{Ch}$ in Figure 7). An example of Arrhenius diagram for the oxychlorination of chromite sample is shown in Figure 8. The apparent activation energy is calculated for $0.00 \leq \mathrm{X} \leq 0.25$ between $600{ }^{\circ} \mathrm{C}$ and $1050{ }^{\circ} \mathrm{C}$ and for $0.40 \leq \mathrm{X} \leq 0.50$ between $925{ }^{\circ} \mathrm{C}$ and $1050{ }^{\circ} \mathrm{C}$. The oxychlorination of chromite for $\mathrm{X} \leq 0.25$ is characterized by the average value of $\mathrm{E}_{\mathrm{a}}$ of about 151 and $57 \mathrm{~kJ} / \mathrm{mol}$ from $600{ }^{\circ} \mathrm{C}$ to $825{ }^{\circ} \mathrm{C}$ and from $825{ }^{\circ} \mathrm{C}$ to 1050 
${ }^{\circ} \mathrm{C}$, respectively. As shown by Figure 8, the apparent activation energy for $0.40 \leq \mathrm{X} \leq 0.50$ is about $262 \mathrm{~kJ} / \mathrm{mol}$. This high value of $\mathrm{E}_{\mathrm{a}}$ indicates that the oxychlorination of magnesium chromite is strongly dependent on the temperature.

An attempt was made to fit mathematically the experimental data of the isothermal oxychlorination of the chromite. Different kinetics equations[11] were used to describe mathematically the evolution of the reaction extent as function of time for the reaction extents lower and higher than 0.30. Eq. [1] seems to be the most appropriate to describe the evolution of the reaction extent $(\mathrm{X} \leq 0.30)$ as function of time for the oxychlorination of chromite between $600{ }^{\circ} \mathrm{C}$ and $800{ }^{\circ} \mathrm{C}$. While, Eq. [2] matches well the oxychlorination data $(\mathrm{X} \leq 0.30)$ for the temperature ranges from $825{ }^{\circ} \mathrm{C}$ to $1050{ }^{\circ} \mathrm{C}$ (Figure 9 b). Similarly, Figure 9 (c) gives the data linearization by using Eq. [2] of the chromite oxychlorination isotherms for $\mathrm{X} \geq 0.35$ between $925^{\circ} \mathrm{C}$ and $1050{ }^{\circ} \mathrm{C}$.

$$
\begin{array}{ll}
1-3(1-X)^{2 / 3}+2(1-X) & =\mathrm{kt} \\
X+(1-X) \ln (1-X) & =\mathrm{kt}
\end{array}
$$

where $\mathrm{k}=$ constant and $\mathrm{t}=$ chlorination time.

Equations [1] and [2] are pertinent to represent pore diffusion control for the spherical and cylindrical pores' shape, respectively, if either the solid or the solid product are porous. Microscopic examination of the chromite samples at $1000{ }^{\circ} \mathrm{C}$, for different reaction extents, showed that the particles become porous (cylindrical shape) with the progress of the reaction. On the other hand, the small dependency of the reaction rate on the particles' size of the sample (refer to Figure 3 ) is probably due to the porous formation inside the particles, thanks to gradual removing of iron and chromium from the chromite. This is also supported by the fact that the particle's size decreased little with the progress of the reaction for the reaction extent as higher as 0.80 .

However, it is difficult to understand clearly the kinetics of the chromite oxychlorination due to complex composition and structure of the chromite. Thus, pore diffusion could occur simultaneously with chemical reaction inside the particles. To clarify some more the kinetics phenomena of the oxychlorination, another series of TGA tests of chromite oxychlorination was performed between $700{ }^{\circ} \mathrm{C}$ and $1040{ }^{\circ} \mathrm{C}$ using a $\mathrm{Cl}_{2}+\mathrm{O}_{2}$ gas mixture with a $\mathrm{Cl}_{2} / \mathrm{O}_{2}$ molar ratio equal to 0.5 . In other words, the partial pressure of chlorine was decreased, leading probably to the decrease of the reactivity of the reactive gases and limiting the pore diffusion phenomena.

Figures 10 (a) and (b) assemble the experimental data obtained for the oxychlorination of chromite with $\mathrm{Cl}_{2}+\mathrm{O}_{2}\left(\mathrm{Cl}_{2} / \mathrm{O}_{2}=0.5\right)$ at $\mathrm{X} \leq 0.30$. The effect of the temperature on the chromite oxychlorination, under the theses conditions, was determined by the Arrhenius diagram. 
The Arrhenius diagrams of the oxychlorination of chromite $(X \leq 0.25)$ for both oxychlorination gas mixtures are compared in Figure 11. Clearly, the reaction rate using $\mathrm{Cl}_{2}+\mathrm{O}_{2}$ with $\mathrm{Cl}_{2} / \mathrm{O}_{2}=4$ is higher than that obtained using $\mathrm{Cl}_{2}+\mathrm{O}_{2}$ with $\mathrm{Cl}_{2} / \mathrm{O}_{2}=0.5$ in whole temperature range explored. While, the values of the apparent activation energy at temperatures lower than 825 ${ }^{\circ} \mathrm{C}$ are similar in both cases. However, at temperatures higher than $825{ }^{\circ} \mathrm{C}$, the value of the $\mathrm{E}_{\mathrm{a}}$ in the case of using $\mathrm{Cl}_{2}+\mathrm{O}_{2}$ with $\mathrm{Cl}_{2} / \mathrm{O}_{2}=0.5$ is higher $(85 \mathrm{~kJ} / \mathrm{mol})$ than that deduced when $\mathrm{Cl}_{2} / \mathrm{O}_{2}$ ratio in the gas mixture was 0.4 . This increase in the value of the $E_{a}$ could be probably due to the presence of a mixed regime, i.e., pore diffusion and chemical reaction inside the pores.

$$
1-(1-\mathrm{X})^{1 / 2}=\mathrm{kt}
$$

where $\mathrm{k}=$ constant and $\mathrm{t}=$ chlorination time.

The mathematical fitting of the experimental data for the chromite oxychlorination with $\mathrm{Cl}_{2}+\mathrm{O}_{2}\left(\mathrm{Cl}_{2} / \mathrm{O}_{2}=0.5\right)$ is represented in Figure 12. As shown by Figure 12 (a), straight lines are obtained by fitting the experimental data using Eq. [1] at temperatures lower or equal to $800{ }^{\circ} \mathrm{C}$. Figure 12 (b) gives the evolution of the reaction extent versus time related by Eq. [3] for the oxychlorination of chromite et temperatures equal or higher than $850{ }^{\circ} \mathrm{C}$. This mathematical fit gathered with the value of $E_{a}$ seem confirmed the mixed rate controlling step of the chromite oxychlorination with $\mathrm{Cl}_{2}+\mathrm{O}_{2}\left(\mathrm{Cl}_{2} / \mathrm{O}_{2}=0.5\right)$ at temperatures higher than $800{ }^{\circ} \mathrm{C}$.

\section{Effect of temperature on the oxychlorination of the simple chromite oxides}

Although the simple oxides of chromite mineral are combined in the spinel structure $\left(\mathrm{Fe}^{2+}\right.$, $\mathrm{Mg})\left(\mathrm{Cr}, \mathrm{Al}, \mathrm{Fe}^{3+}\right)_{2} \mathrm{O}_{4}$, it was worthwhile to study the effect of temperature on the oxychlorination of simple oxides : $\mathrm{Cr}_{2} \mathrm{O}_{3}, \mathrm{Fe}_{(1-\mathrm{x})} \mathrm{O}, \mathrm{Fe}_{2} \mathrm{O}_{3}, \mathrm{MgO}$ and $\mathrm{Al}_{2} \mathrm{O}_{3}$. Their composition and structures were determined by SEM and XRD analysis ${ }^{[4]}$. The tests were carried out in boat experiments using the horizontal setup. Several grams were used for each test. An oxychlorinating gas mixture composed of $\mathrm{Cl}_{2}$ +air with a $\mathrm{Cl}_{2}$ /air molar ratio equal to 1 was used and the oxychlorination time was fixed at 2 hours. The results are given in Figure 13 as evolution of PWL versus time. This figure contains also the results of the oxychlorination of chromite in the same conditions used as for the simple oxides.

Details concerning the behavior of these oxides in the $\mathrm{Cl}_{2}+\mathrm{O}_{2}$ were given previously[4]. Iron oxides are the most reactive towards the oxychlorinating gas mixture and almost full reaction was obtained at about $900{ }^{\circ} \mathrm{C}$. The reaction product was identified as $\mathrm{FeCl}_{3}$. The reactivity of $\mathrm{Cr}_{2} \mathrm{O}_{3}$ seems to be lower than that of iron oxides especially at higher temperatures and the reaction product was chromium oxychloride $\left(\mathrm{CrO}_{2} \mathrm{Cl}_{2}\right)$. Magnesium oxide seems to be inert up to about 850 ${ }^{\circ} \mathrm{C}$ and only 20 pct of sample had reacted at $1000{ }^{\circ} \mathrm{C}$ generating magnesium chloride. While, no reaction of aluminum oxide with the oxychlorinating gas mixture was observed even at $1000{ }^{\circ} \mathrm{C}$. Chromite started to react with $\mathrm{Cl}_{2}+$ air from about $600{ }^{\circ} \mathrm{C}$ and less than 30 pct of the sample had 
reacted at $1000{ }^{\circ} \mathrm{C}$ during 2 hours. This series of experiments revealed roughly the reactivity of these oxides towards oxychlorinating gas mixtures as well as the main products of the reactions.

More consist information was obtained during the treatment of these oxides using TG measurements in the absence of the mass transfer phenomena. Wüstite $\left(\mathrm{Fe}_{(1-\mathrm{x})} \mathrm{O}\right)$ was not tested because it transformed rapidly into hematite $\left(\mathrm{Fe}_{2} \mathrm{O}_{3}\right)$ during the chlorination. Aluminum oxide was not taken into consideration due to its refractive nature towards chlorine in absence of a reducing atmosphere[4].

The other oxides $\left(\mathrm{Cr}_{2} \mathrm{O}_{3}, \mathrm{Fe}_{2} \mathrm{O}_{3}\right.$, and $\left.\mathrm{MgO}\right)$ were oxychlorinated with $\mathrm{Cl}_{2}+\mathrm{O}_{2}$ gas mixture with $\mathrm{Cl}_{2} / \mathrm{O}_{2}$ molar ratio equal to 4 . Kinetics aspects of the oxychlorination $\mathrm{Cr}_{2} \mathrm{O}_{3}$ and $\mathrm{MgO}$ were reported in Reference [12] and [10], respectively. Figure 14 compares the temperature effects on the oxychlorination of the chromite and its simple oxides. The following observations could be deduced from this figure :

1. Concerning the oxychlorination of chromite (first stage), $\mathrm{Cr}_{2} \mathrm{O}_{3}$, and $\mathrm{Fe}_{2} \mathrm{O}_{3}$ :

a. chromite oxychlorination is characterized by a value of the apparent activation energy of about $151 \mathrm{~kJ} / \mathrm{mol}$ between $600{ }^{\circ} \mathrm{C}$ and $825^{\circ} \mathrm{C}$. About the same value of the $\mathrm{Ea}(\approx 148$ $\mathrm{kJ} / \mathrm{mol}$ ) was obtained for the hematite oxychlorination. Chromium (III) oxide oxychlorination proceeds with an $\mathrm{E}_{\mathrm{a}}$ value of about $46 \mathrm{~kJ} / \mathrm{mol}^{[12]}$ at temperatures higher than $700{ }^{\circ} \mathrm{C}$. The reaction rate of chromite and that of hematite with $\mathrm{Cl}_{2}+\mathrm{O}_{2}$ at temperatures lower or equal to $800{ }^{\circ} \mathrm{C}$ are of the same order of magnitude. It may be speculated that for the first stage of the chromite $\left(\mathrm{FeCr}_{2} \mathrm{O}_{4}\right)$ reaction with $\mathrm{Cl}_{2}+\mathrm{O}_{2}$ at temperatures $\leq 800{ }^{\circ} \mathrm{C}$ depended on the oxychlorination rate of iron oxides.

b. as at temperatures higher than $825^{\circ} \mathrm{C}$, the oxychlorination of chromite and that of $\mathrm{Cr}_{2} \mathrm{O}_{3}$ were characterized by the similar values of the $\mathrm{E}_{\mathrm{a}}$ and reaction rates, it seems that the global reaction rate of chromite is affected by the oxychlorination rate of $\mathrm{Cr}_{2} \mathrm{O}_{3}$.

2. Concerning the oxychlorination of chromite (second stage), $\mathrm{Cr}_{2} \mathrm{O}_{3}$, and $\mathrm{MgO}$ : the value of $\mathrm{E}_{\mathrm{a}}$ deduced from the data of chromite $(\mathrm{X} \geq 0.4), \mathrm{Cr}_{2} \mathrm{O}_{3}$, and $\mathrm{MgO}$ oxychlorination are about $262,46^{[12]}$ and $214 \mathrm{~kJ} / \mathrm{mol}^{[10]}$, respectively. The reaction rate of $\mathrm{Cr}_{2} \mathrm{O}_{3}$ is much higher than that of chromite. Thus, it has be supposed that the oxychlorination of chromite for $\mathrm{X} \geq 0.4\left(\mathrm{MgCr}_{2} \mathrm{O}_{4}\right)$ depended on the $\mathrm{MgO}$ reaction rate with $\mathrm{Cl}_{2}+\mathrm{O}_{2}$ as the reaction rates and the values of $\mathrm{E}_{\mathrm{a}}$ are comparable.

Although these similarities of the chromite oxychlorination with the reactions of its simple oxides with $\mathrm{Cl}_{2}+\mathrm{O}_{2}$, other phenomena such as : the chemical bonds between the simple oxides in the chromite spinel structure, the interaction between the reaction products and chromite, the formation of the lacunaire spinels, etc., are expected to affect the chromite oxychlorination. 


\section{CONCLUSIONS}

The presence of a reducing atmosphere was necessary to achieve a complete reaction of the chromite mineral with chlorine. Only iron chromite could be oxychlorinated at temperatures lower than $1000{ }^{\circ} \mathrm{C}$ using nonisothermal conditions.

The oxychlorination of the chromite occurred in two stages characterized by widely different reactivities of chromite towards $\mathrm{Cl}_{2}+\mathrm{O}_{2}$ gaseous mixture. Similarly, the effect of the temperature changed significantly with the progress of the reaction. Iron chromite seems to be more reactive than magnesium chromite in the oxychlorinating gases.

The oxychlorination of the chromite with $\mathrm{Cl}_{2}+\mathrm{O}_{2}\left(\mathrm{Ch}_{2} / \mathrm{O}_{2}=4\right)$ for the reaction extents up 0.30 proceeded with an apparent activation energy of about 151 and $57 \mathrm{~kJ} / \mathrm{mol}$ for the temperatures ranges of $600{ }^{\circ} \mathrm{C}$ to $825^{\circ} \mathrm{C}$ and $825{ }^{\circ} \mathrm{C}$ to $1050{ }^{\circ} \mathrm{C}$. Oxychlorination with a $\mathrm{Cl}_{2}+\mathrm{O}_{2}$ mixture having a $\mathrm{Cl}_{2} / \mathrm{O}_{2}$ ratio of 0.5 , at temperatures lower than $825{ }^{\circ} \mathrm{C}$ led to the similar temperature effect on the reaction rate. While a value of $E_{a}$ of about $85 \mathrm{~kJ} / \mathrm{mol}$ was obtained for the oxychlorination at temperatures higher than $825^{\circ} \mathrm{C}$. The oxychlorination rate using $\mathrm{Cl}_{2}+\mathrm{O}_{2}$ with $\mathrm{Cl}_{2} / \mathrm{O}_{2}=4$ is systematically higher than that obtained using a $\mathrm{Cl}_{2}+\mathrm{O}_{2}$ with $\mathrm{Cl}_{2} / \mathrm{O}_{2}=0.5$.

The second stage of the chromite oxychlorination $(X>0.35)$ is strongly dependent on the reaction temperature and it was characterized by a value $\mathrm{E}_{\mathrm{a}}$ of about $262 \mathrm{~kJ} / \mathrm{mol}$ between $925{ }^{\circ} \mathrm{C}$ and $1050{ }^{\circ} \mathrm{C}$.

The effects of the temperature on the chromite oxychlorination may be roughly explained by the dependency of the temperature on the reaction of the simple chromite constituents.

\section{ACKNOWLEDGMENTS}

This work was performed in the frame of contract $\mathrm{N}^{\circ}$ BRE2-CT92-0173 thanks to the financial support of the European Union (DG-XII). The authors thank Dr. H. L. Schmidt for discussion, suggestion and help.

They also would like to thank Dr. J. C. Mugica, Dr. R. Solozabal (INASMET, San Sebastian, Spain) and Dr. M. Coelho (INETI, Lisbon, Portugal) for technical discussions. Authors are indebted to Dr. A. Bonazébi, Dr. M. Djona, Dr. S. Ivanaj, Dr. N. Menad, Dr. N. Mirghaffari for discussions and help on different subjects and to Mrs. C. Richard for technical and administrative support. 


\section{REFERENCES}

1 B.G. Korshunov: Metallurgical Review of MMIJ, 1992, Vol. 8, (2), pp. 1-33.

2 I. Gaballah and M. Djona: Metall. Mater. Trans. B, 1995, vol. 26B, pp. 41-50.

3 I. Gaballah: Fifth Report of European Union Contract No BRE2-CT92-0173, Institut National Polythecnique de Lorraine, Laboratoire Environnement et Mineralurgie, Nancy, France, October 1995.

4 N. Kanari: Ph.D. Thesis, Institut National Polythechnique de Lorraine, Laboratoire Environnement et Mineralurgie, Nancy, France, November 1995, 209 pages.

5 N. Kanari and I. Gaballah: Paper presented at Proc. of the TMS Annual Meeting, Orlando, Florida, February 9-13, 1997, EPD Congress 1997, Ed. by B. Mishra, Pub. by TMS, pp. 5771.

6 N. Kanari and I. Gaballah: Paper presented at Proc. of the TMS Annual Meeting, San Antonio, Texas, February 15-19, 1998, Light Metals 1998, Ed. by Barry J. Welch, Published by TMS, pp. $1333-1341$.

7 N. Kanari, E. Allain, and I. Gaballah: Metall. Mater. Trans. B, 1999, vol. 30B, vol. 30B, pp. 577-587.

8 Anonymous : in Handbook of Chemistry and Physics, (66 th edition, Eds. R.C. Weast, M.J. Astle, and W.H. Beyer, CRC Press, Boca Raton, Florida, USA, 1986), pp. D193 - D194.

9 P. Pascal : in Nouveau Traité de Chimie Minérale, Masson et Cie, eds., 1959, tome XIV, p. 135.

10 N. Kanari, I. Gaballah, and E. Allain: Metall. Mater. Trans. B, 1999, in press.

11 J. Szekely, J.W. Evans and H.Y. Sohn, in Gas-Solid Reactions, Academic Press, New York, NY. 1976, pp. 68-70, 73-88, 109-131 and 232-240.

12 I. Gaballah, S. Ivanaj, and N. Kanari: Metall. Mater. Trans. A, 1998, vol. 29A, pp. 12991308. 


\title{
Kinetics of Oxychlorination of Chromite : Part I. Effect of Temperature
}

\author{
N. KANARI, I. GABALLAH and E. ALLAIN* \\ Mineral Processing and Environmental Engineering Team, \\ LEM $^{\mathrm{a}}$, CNRS ${ }^{\mathrm{b}} \mathrm{UMR}^{7569}, \mathrm{ENSG}^{\mathrm{c}}$, INPL ${ }^{\mathrm{d}}$, BP 40, 54501 Vandœuvre, France \\ * University of Missouri-Rolla, School of Mines and Metallurgy, Center for Pyrometallurgy \\ 210 Fulton Hall, 65401 Rolla, MO, USA
}

\section{FIGURE CAPTIONS}

Figure 1 : Thermogravimetric analysis of chromite $(a)$ in different chlorinating gas mixtures and (b) derivative of weight losses versus temperature.

Figure 2 : Evolution of vapor pressure of several chlorides as a function of temperature ${ }^{[8,9]}$.

Figure 3 : Isothermal oxychlorination with $\mathrm{Cl}_{2}+\mathrm{O}_{2}$ of two grain sizes of chromite at $1050{ }^{\circ} \mathrm{C}$.

Figure 4 : SEM results of oxychlorination residues of chromite at $1050{ }^{\circ} \mathrm{C}$ for different reaction extents.

Figure 5 : Isotherms of the chromite oxychlorination using $(a)$ different gas flow rate and $(b)$ its effect on the reaction rate.

Figure 6 : Isotherms of the chromite oxychlorination with $\mathrm{Cl}_{2}+\mathrm{O}_{2}$ between :
(a) : $600{ }^{\circ} \mathrm{C}$ and $800{ }^{\circ} \mathrm{C}(\mathrm{X} \leq 0.30)$,
(b) : $850{ }^{\circ} \mathrm{C}$ and $1050{ }^{\circ} \mathrm{C}(\mathrm{X} \leq 0.30)$,
(c) : $925^{\circ} \mathrm{C}$ and $1050{ }^{\circ} \mathrm{C}(\mathrm{X} \leq 0.80)$.

Figure 7 : Evolution of the activation energy as a function of the reaction extent.

Figure 8 : Example of Arrhenius plot of the chromite oxychlorination.

Figure 9 : Mathematical fitting of the data of the chromite oxychlorination for :

(a) : $\mathrm{T} \leq 800{ }^{\circ} \mathrm{C}, \mathrm{X} \leq 0.30$ using Eq. [1],

(b) : $\mathrm{T} \geq 825^{\circ} \mathrm{C}, \mathrm{X} \leq 0.30$ using Eq. [2],

(c) : $\mathrm{T} \geq 925^{\circ} \mathrm{C}, \mathrm{X} \geq 0.35$ using Eq. [2].

Figure 10 : Isotherms of the chromite oxychlorination with $\mathrm{Cl}_{2}+\mathrm{O}_{2}$ having a $\mathrm{Ch} / \mathrm{O}_{2}$ molar ratio equal to 0.5 for $(a) \mathrm{T} \leq 800{ }^{\circ} \mathrm{C}$ and $(b) \mathrm{T} \geq 850{ }^{\circ} \mathrm{C}$.

Figure 11 : Comparison of Arrhenius plots of the chromite oxychlorination with $\mathrm{Cl}_{2}+\mathrm{O}_{2}$ gaseous mixtures having different $\mathrm{Cl}_{2} / \mathrm{O}_{2}$ molar ratios.

Figure 12 : Mathematical fitting of the oxychlorination data at $(a) \mathrm{T} \leq 800{ }^{\circ} \mathrm{C}$ and $(b) \mathrm{T} \geq 850{ }^{\circ} \mathrm{C}$ using Eqs. [1] and [3], respectively.

Figure 13 : Oxychlorination of chromite and its simple oxides with $\mathrm{Cl}_{2}+$ air between $600{ }^{\circ} \mathrm{C}$ and $1000{ }^{\circ} \mathrm{C}$ for 2 hours using boat experiments.

Figure 14 : Comparison of Arrhenius plots of the oxychlorination of chromite, $\mathrm{Fe}_{2} \mathrm{O}_{3}, \mathrm{Cr}_{2} \mathrm{O}_{3}$, and $\mathrm{MgO}$. 

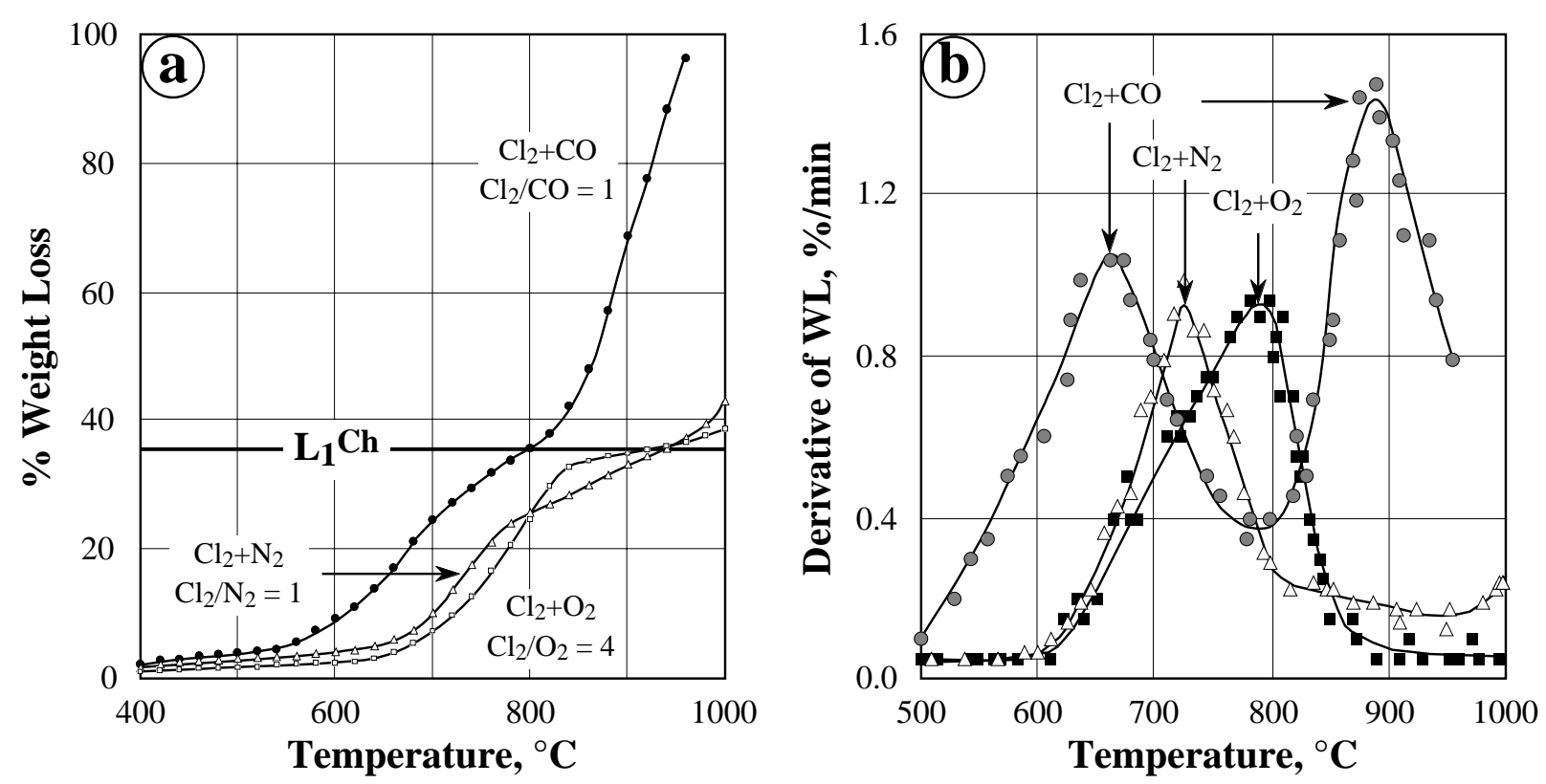

Figure 1 : Thermogravimetric analysis of chromite $(a)$ in different chlorinating gas mixtures and $(b)$ derivative of weight losses versus temperature.

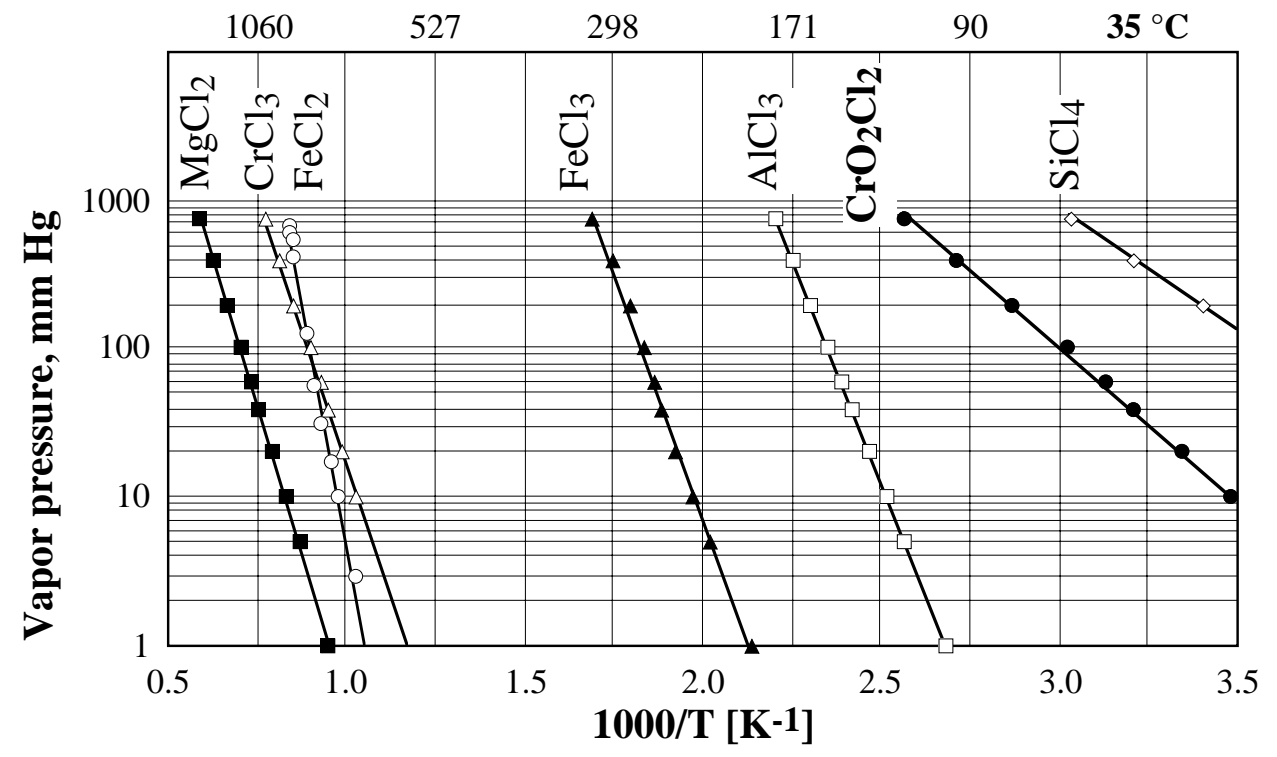

Figure 2 : Evolution of vapor pressure of several chlorides as a function of temperature[8,9]. 


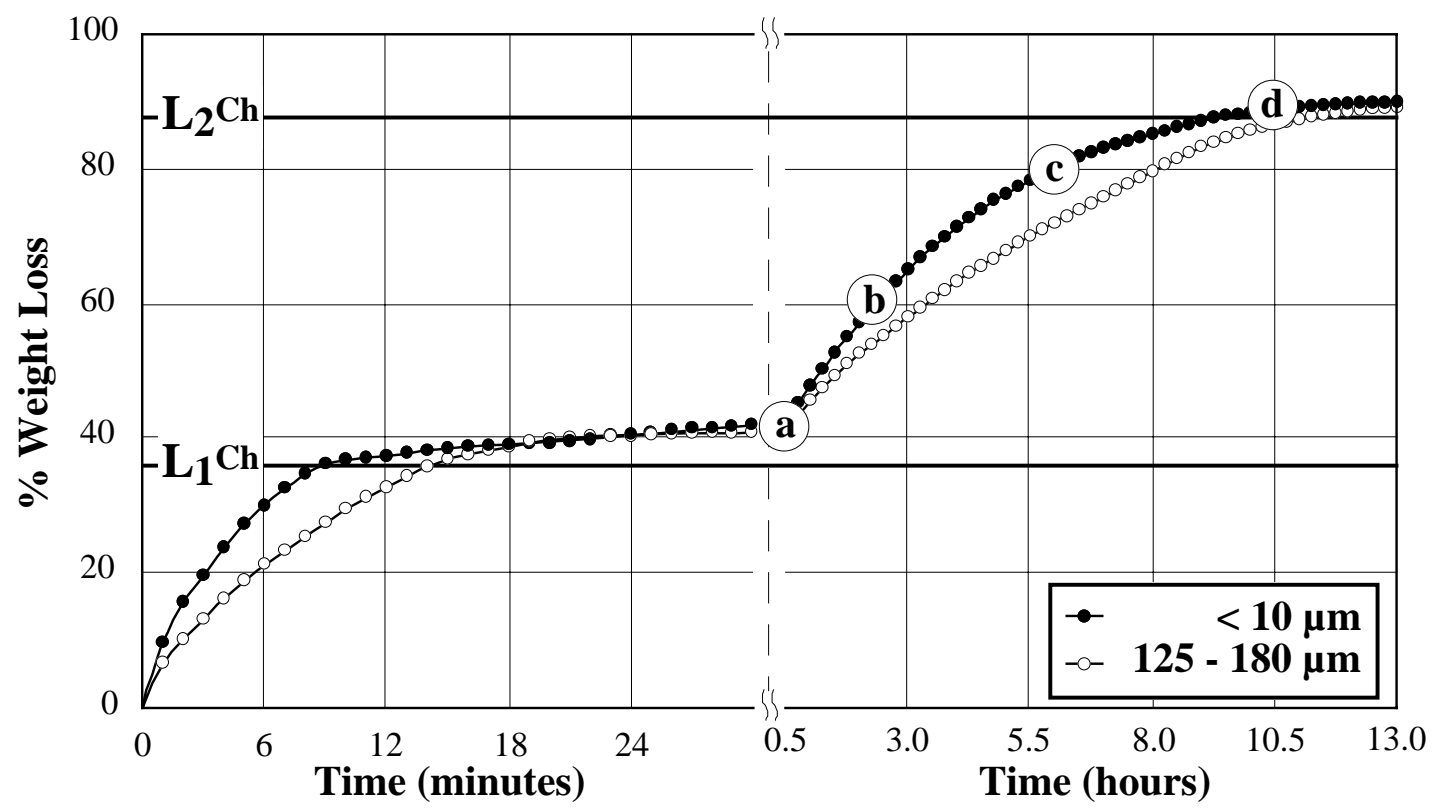

Figure 3 : Isothermal oxychlorination with $\mathrm{Cl}_{2}+\mathrm{O}_{2}$ of two grain sizes of chromite at $1050{ }^{\circ} \mathrm{C}$.

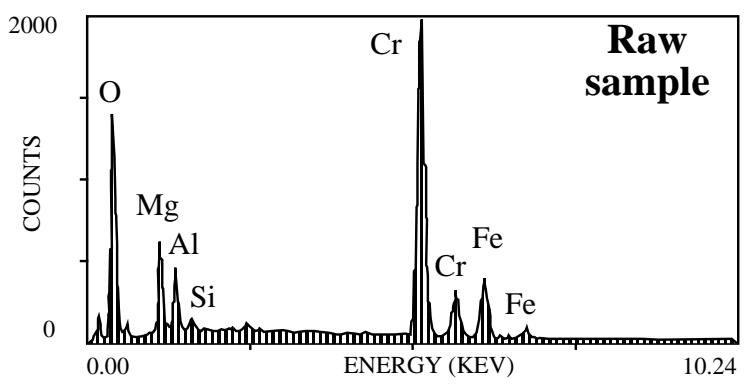
$\mathrm{a}: \mathrm{X}=0.40$
$\mathrm{b}: \mathrm{X}=0.60$,
$\mathrm{c}: \mathrm{X}=0.80$,
$\mathrm{d}: \mathrm{X}=0.88$.
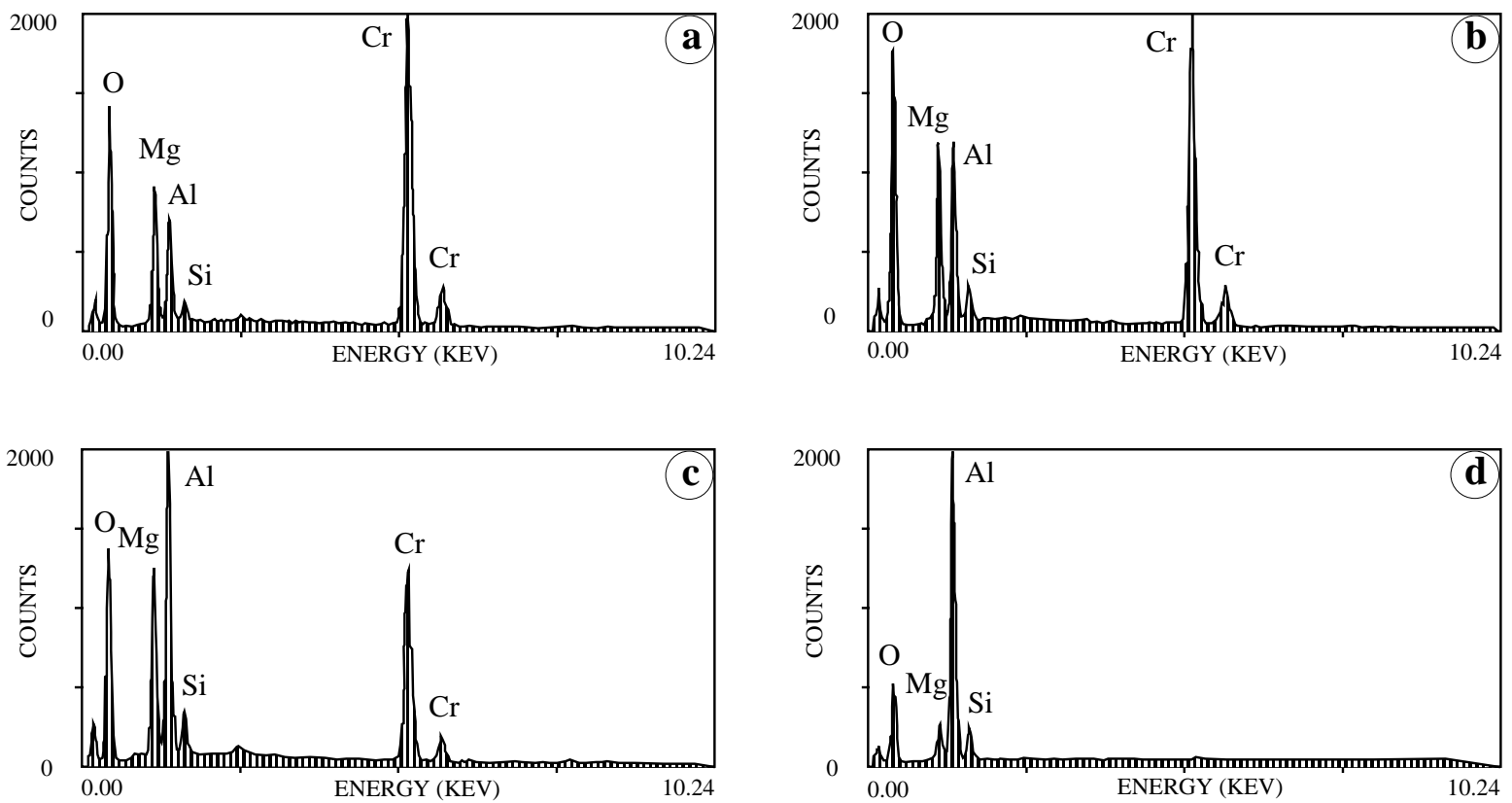

Figure 4 : SEM results of oxychlorination residues of chromite at $1050{ }^{\circ} \mathrm{C}$ for different reaction extents. 

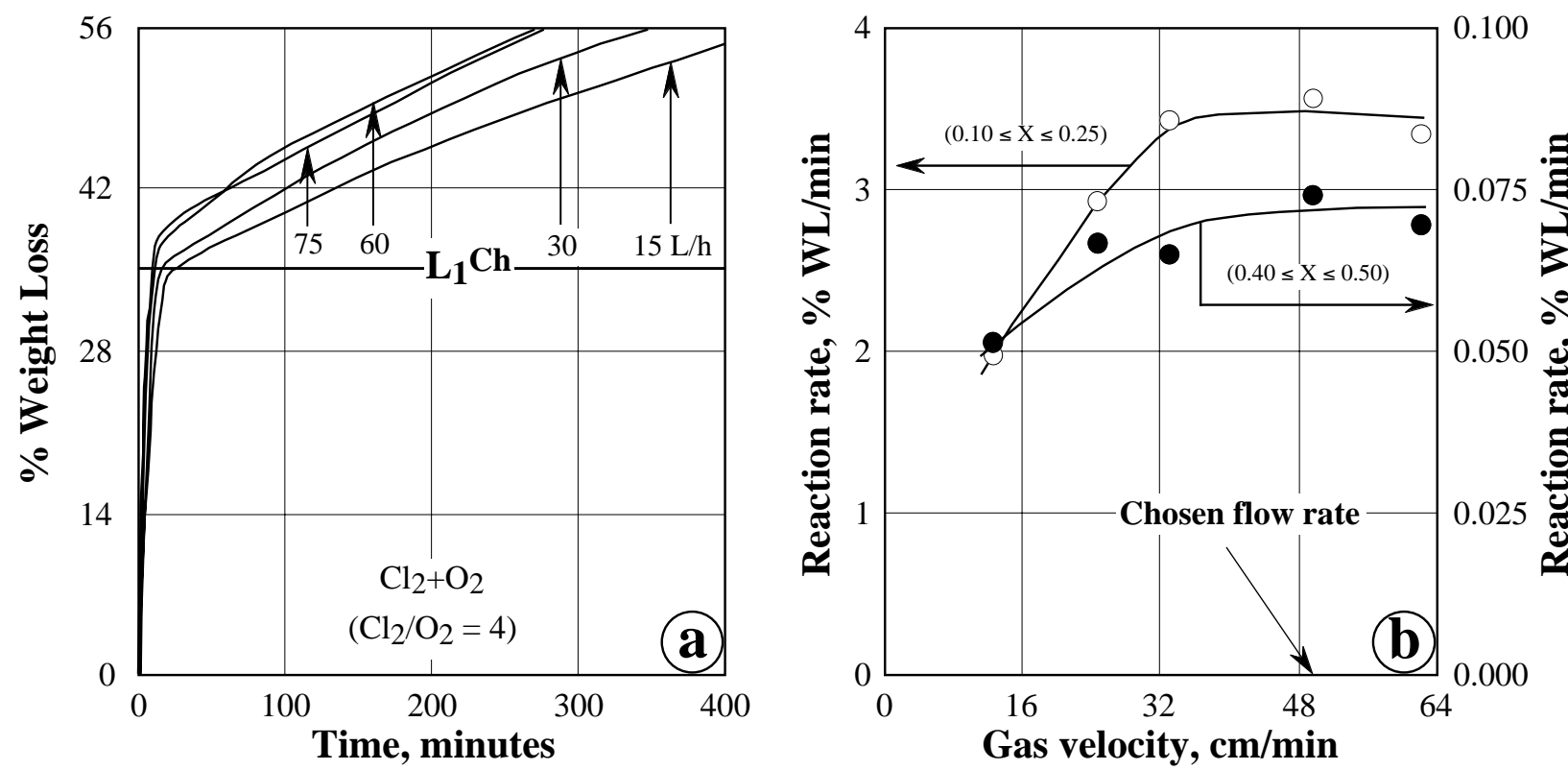

Figure 5 : Isotherms of the chromite oxychlorination using $(a)$ different gas flow rate and $(b)$ its effect on the reaction rate .
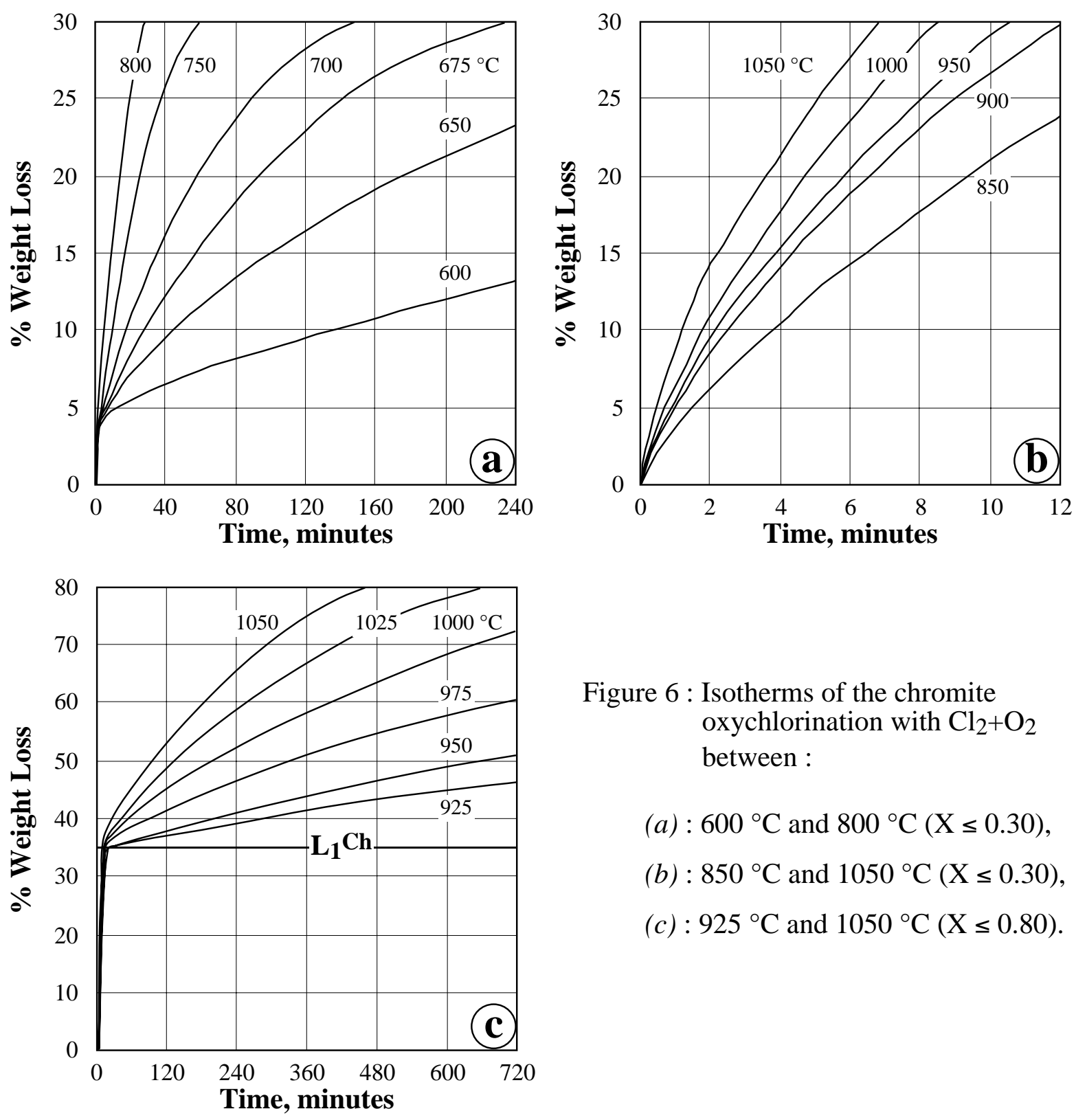

Figure 6 : Isotherms of the chromite oxychlorination with $\mathrm{Cl}_{2}+\mathrm{O}_{2}$ between :

(a) : $600{ }^{\circ} \mathrm{C}$ and $800{ }^{\circ} \mathrm{C}(\mathrm{X} \leq 0.30)$,

(b) : $850{ }^{\circ} \mathrm{C}$ and $1050{ }^{\circ} \mathrm{C}(\mathrm{X} \leq 0.30)$,

(c) : $925^{\circ} \mathrm{C}$ and $1050{ }^{\circ} \mathrm{C}(\mathrm{X} \leq 0.80)$. 


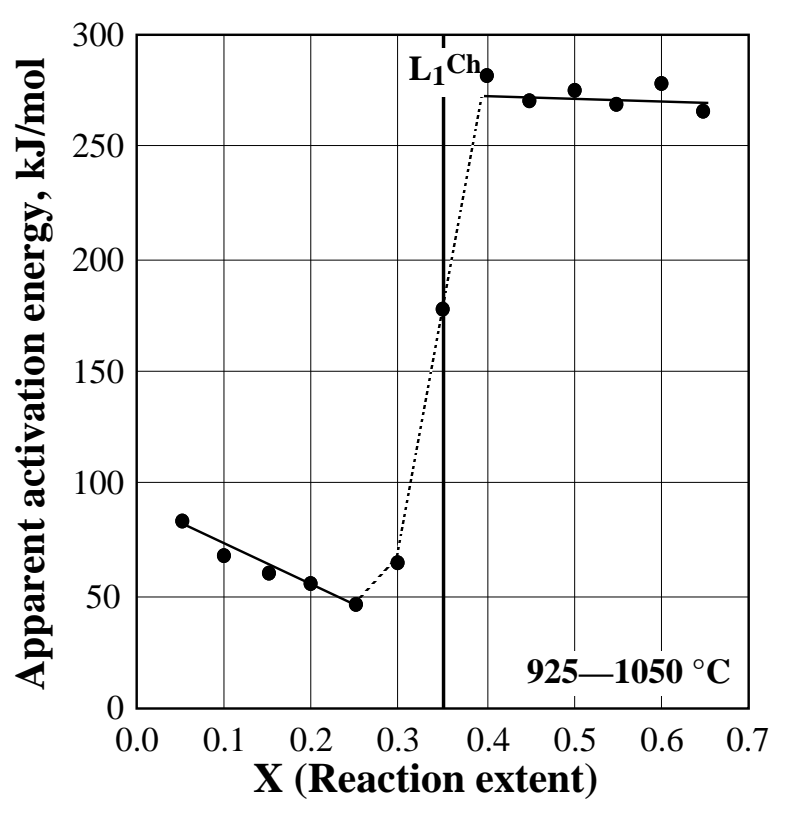

Figure 7 : Evolution of the activation energy as a function of the reaction extent.
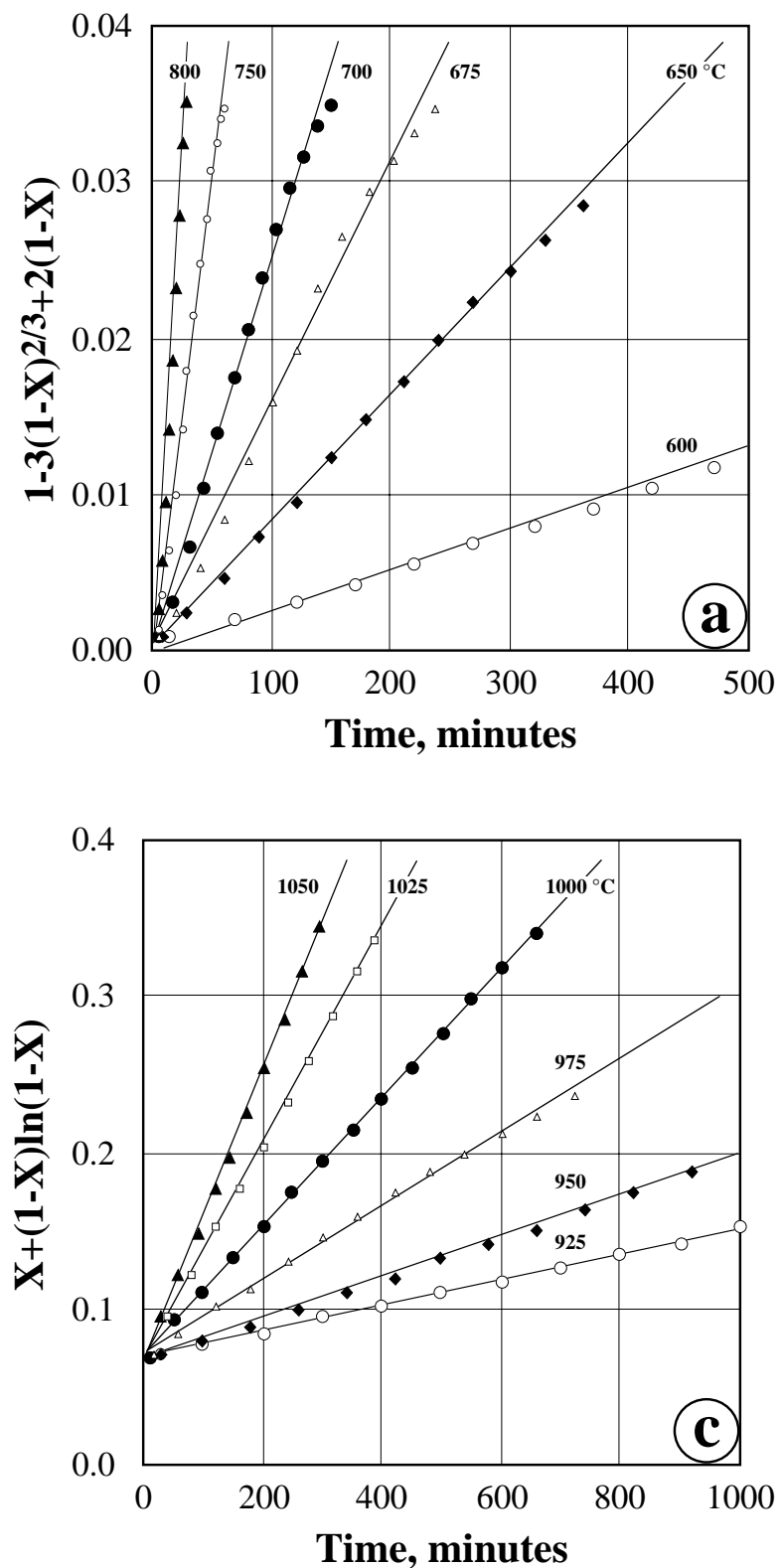

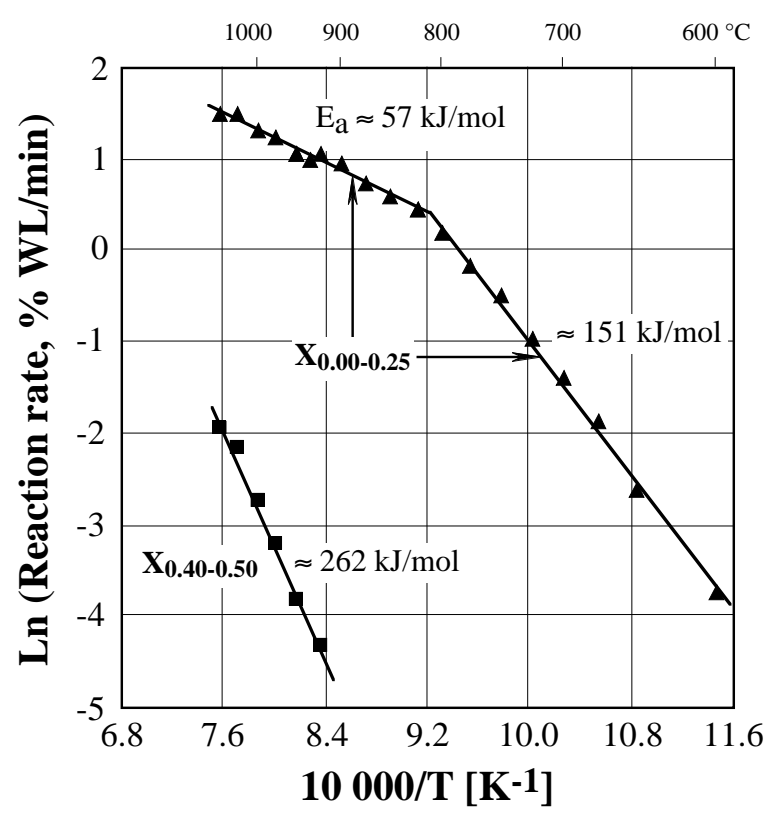

Figure 8 : Example of Arrhenius plot of the chromite oxychlorination.

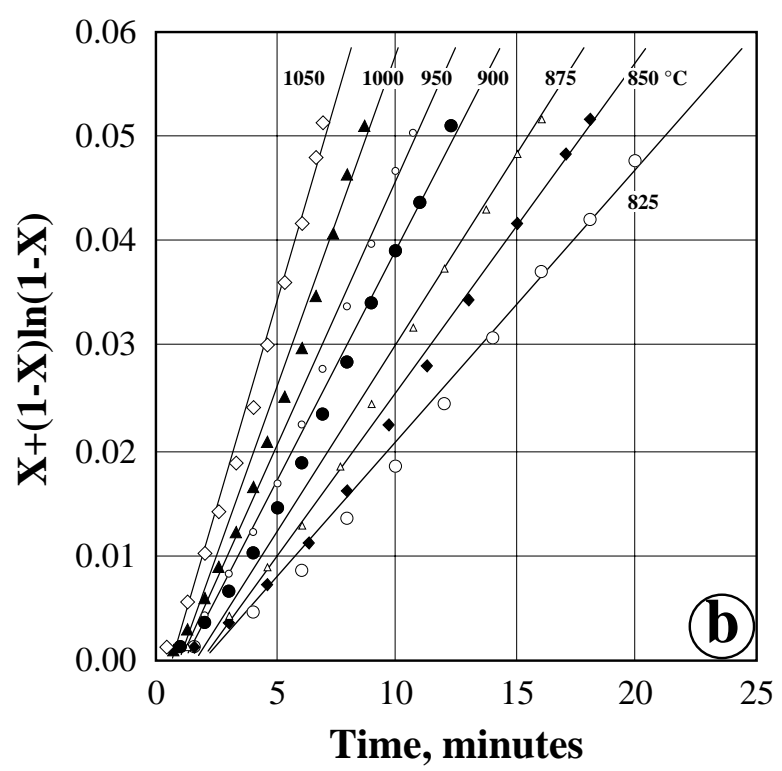

Figure 9 : Mathematical fitting of the data of the chromite oxychlorination for :
(a) : $\mathrm{T} \leq 800{ }^{\circ} \mathrm{C}, \mathrm{X} \leq 0.30$ using Eq. [1],
(b) : $\mathrm{T} \geq 825^{\circ} \mathrm{C}, \mathrm{X} \leq 0.30$ using Eq. [2],
(c) : $\mathrm{T} \geq 925^{\circ} \mathrm{C}, \mathrm{X} \geq 0.35$ using Eq. [2]. 

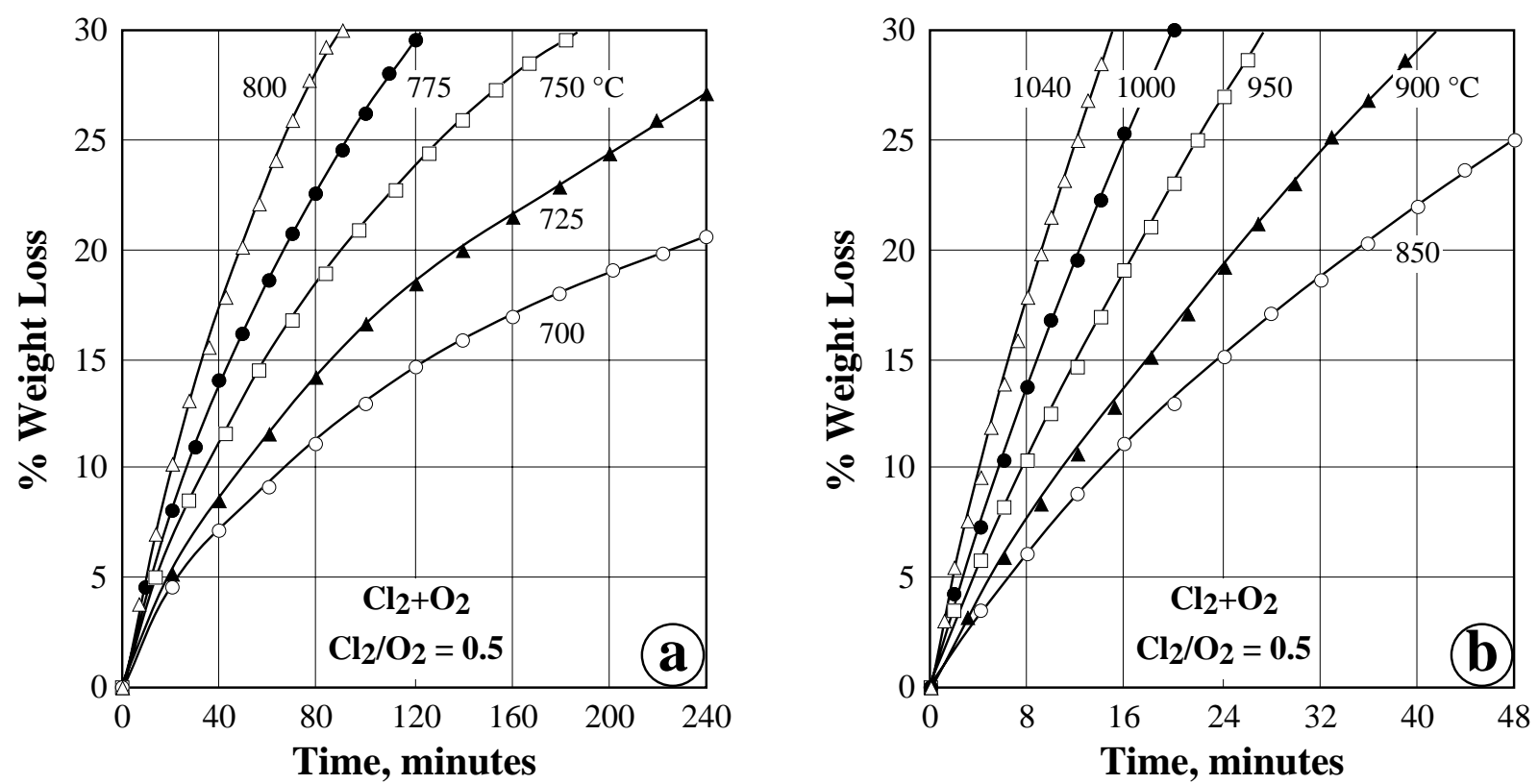

Figure 10 : Isotherms of the chromite oxychlorination with $\mathrm{Cl}_{2}+\mathrm{O}_{2}$ having a $\mathrm{Cl}_{2} / \mathrm{O}_{2}$ molar ratio equal to 0.5 for $(a) \mathrm{T} \leq 800{ }^{\circ} \mathrm{C}$ and $(b) \mathrm{T} \geq 850^{\circ} \mathrm{C}$.

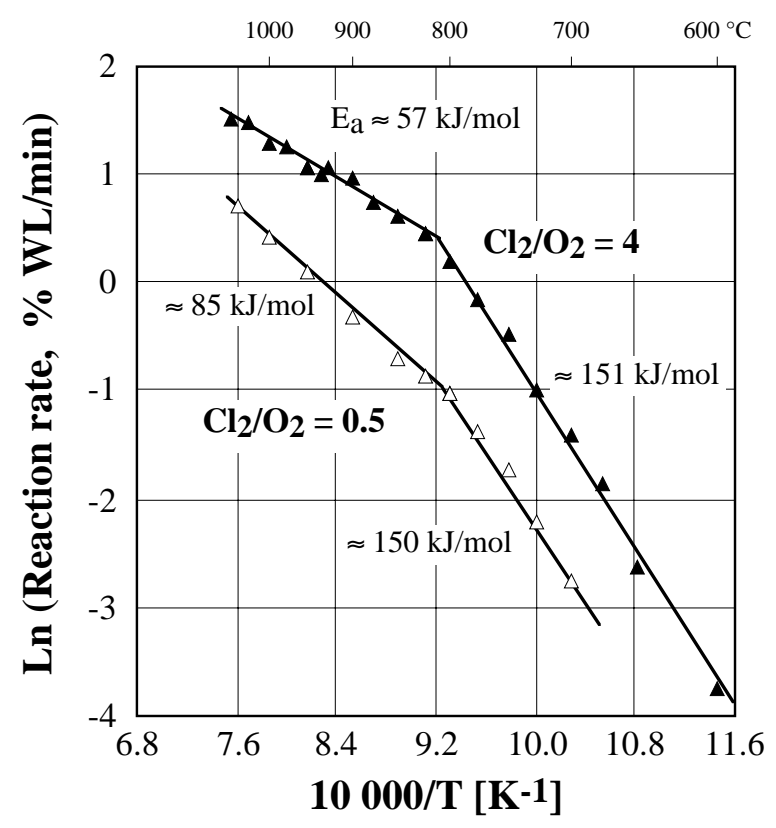

Figure 11 : Comparison of Arrhenius plots of the chromite oxychlorination with $\mathrm{Cl}_{2}+\mathrm{O}_{2}$ gaseous mixtures having different $\mathrm{Cl}_{2} / \mathrm{O}_{2}$ molar ratios. 

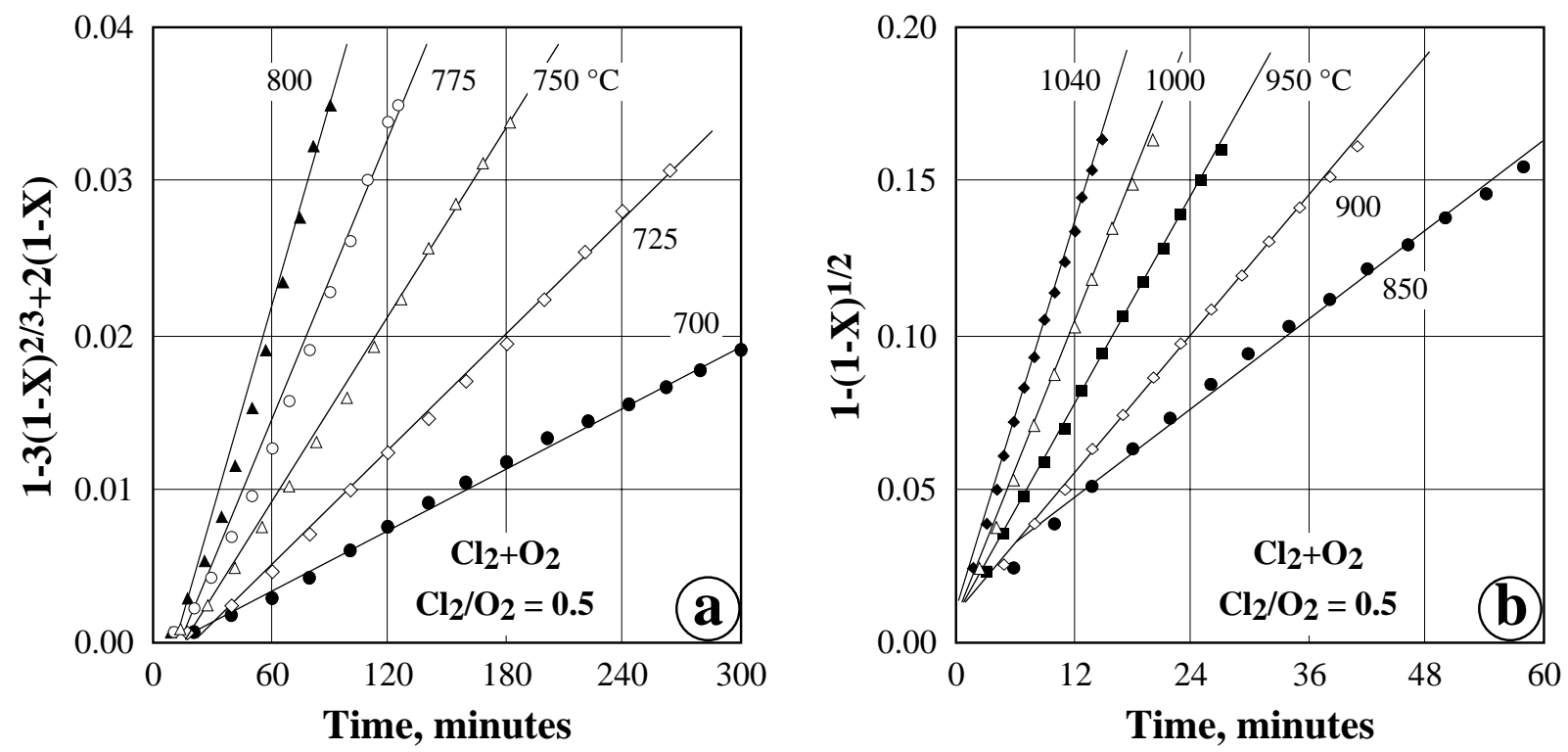

Figure 12 : Mathematical fitting of the oxychlorination data at $(a) \mathrm{T} \leq 800{ }^{\circ} \mathrm{C}$ and (b) $\mathrm{T} \geq 850{ }^{\circ} \mathrm{C}$ using Eqs. [1] and [3], respectively.

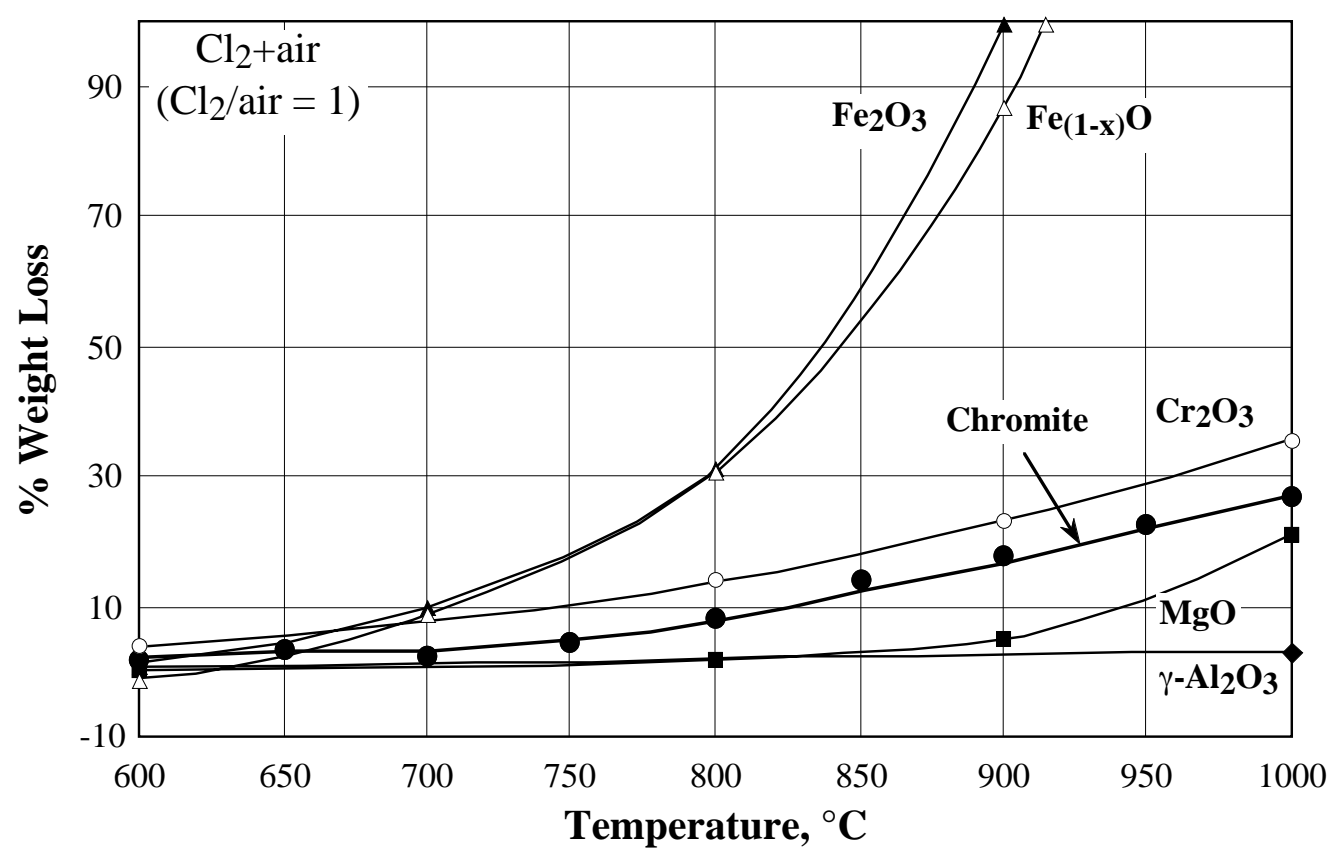

Figure 13 : Oxychlorination of chromite and its simple oxides with $\mathrm{Cl}_{2}+$ air between $600{ }^{\circ} \mathrm{C}$ and $1000{ }^{\circ} \mathrm{C}$ for 2 hours using boat experiments. 


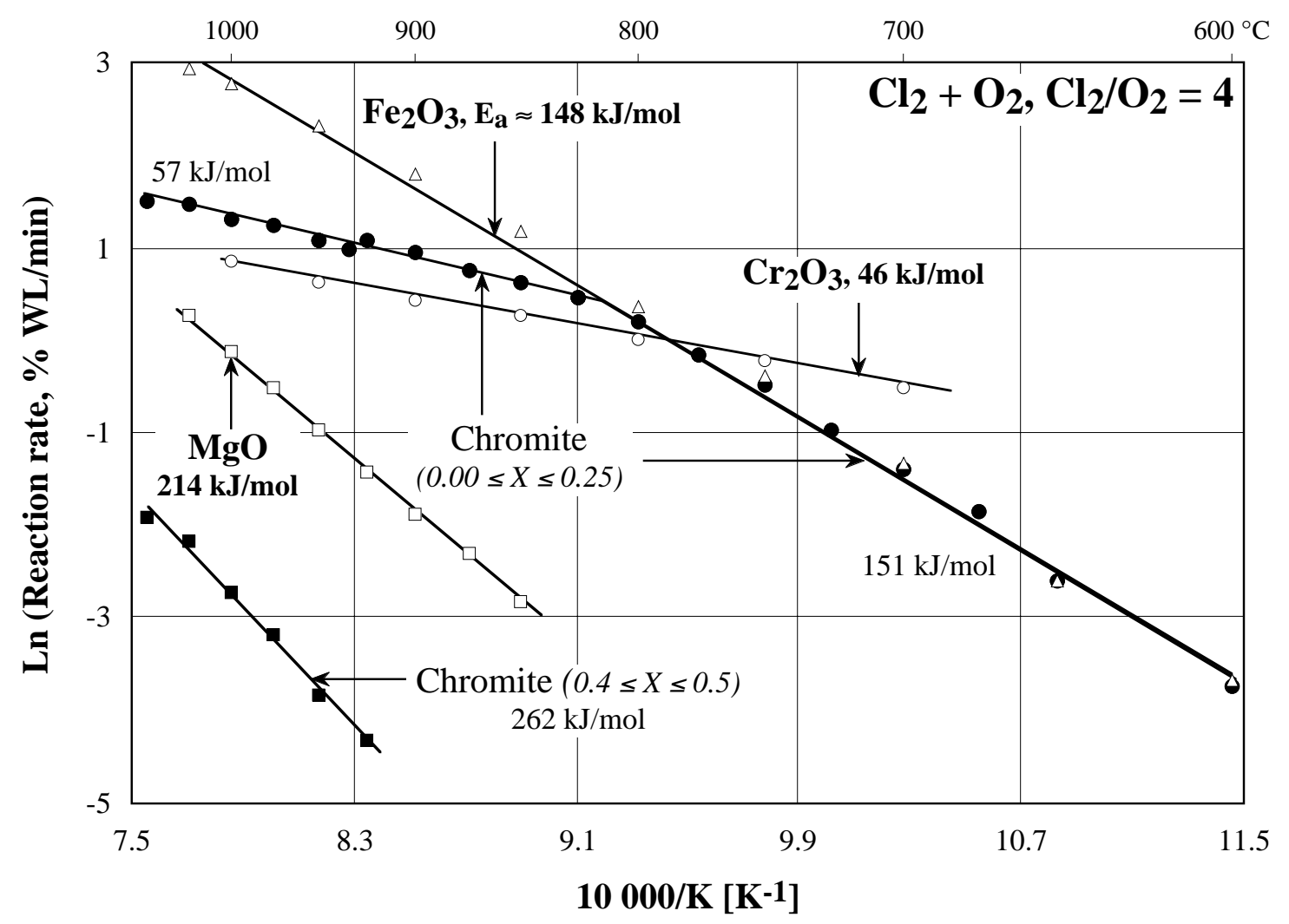

Figure 14 : Comparison of Arrhenius plots of the oxychlorination of chromite, $\mathrm{Fe}_{2} \mathrm{O}_{3}, \mathrm{Cr}_{2} \mathrm{O}_{3}$, and $\mathrm{MgO}$. 